Our own mechanics' institutes and kindred undertakings are just now commencing their autumnal session. We commend to them the consideration whether the principle of self-help cannot be more definitely recognised than has hitherto been the case. We hear with pleasure that the Working Men's College in Great Ormond Street is projecting an extension of its scientific programme in the approaching session. Let men and women be treated, not as artisans, mechanics, or gentlemen, but simply as men and women, standing toward the teacher only in the position of recipients of something which he feels the power and necessity of imparting; let no thought of any other relationship enter into this connection; and we predict for this and other equally admirable institutions a far wider popularity and usefulness than they have hitherto enjoyed.

\section{REPLY TO PROFESSOR HUXLEY'S INAUGURAL ADDRESS AT LIVERPOOL ON THE QUESTTON OF THE ORIGIN OF LIFE.}

\section{II.}

I HE main argument must now be resumed: this having been cnly temporarily laid aside in order to inquire how far Prof. Huxley's "long chain of evidence" touched the real point at issue.

Flaving shown that, in reality, this has no immediate bearing upon the question in dispute, and having endeavoured to show to what extent the burden of proof rests with Prof. Huxley and others who affirm the universality of Redi's doctrine, it has now to be shown what evidence can be brought forward which may influence our judgment in the selection of one or other of the two possible modes by which alone the minute motionless specks of Living matter appearing in certain solutions can be supposed to originate. We must inquire, as much as possible independently of theoretical considerations, towards which of the two modes of origin--the gern or the germless-the evidence should induce us to lean.

It will be well, however, in the first place, to submit the following considerations to those who wish to form an unbiassed opinion upon the subject. Supposing that the minutest visible specks of living matter have originated from the growth of preexisting invisible germs, there is still no reason whatever to induce us to believe that the invisible portions of Living matter would differ from visible portions in their power of resisting the destructive influence of heat. Whether visible or invisible, we are supposed only to have to do with Living matter, and it cannot be supposed that the qualities of this matter wonld vary simply because it existed in a state so minute as to elude our observation. What has been found to hold good, therefore, concerning the inability of visible Living matter to resist the destructive agency of heat may also be presumed to hold goorl for any invisible portions of Living matter. Invisible germs mus be supposed to be amenable to the same influences as those which affect visible germs. * If the latter are destroyed by any given amount of heat, we should have every reason to expect that give former would also be destroyed under similar circumstances. $t$

It seems to me that the only means which we at present possess of throwing light upon this question, as to whether the minute Living things which appear under our eyes, in certain solutions,

* It was suggested to me by a friend that extreme smallness of size might be a protection against the infuence of heat; in illustration of which possibility my attention was called to the fact that the water in capillary tubes will not freeze at times when that in larger vessels will become solidified. But although the water in the capillary tube does not freeze, this is due rather to some aliered molecular condition of the fluid, and not because its temperature is not lowered just as much as that contained in the larger vesse which does freeze. I cannot see how smallness of size can confer immunity from alterations of temperature-more especially of any particles, howeve minute, which are contained within hermetically sealed fiasks retained at a given theat for four hours.

$t$ I have already pointed out (note p. $4 x 0$ ) that the problem is utterly im possible to be solved if this be not granted as a probability; and that, simi larly, without the concession that invisible crystalline matter resembled in its properties visiole crystalline matter, it would be equally impossible to consider it as proved that a crystal can originate in a solution de $10 \% 0$, ind pendently of a pre-existing crystalline germ. really derive their origin from pre-existing Living things, or spring into being de novo, is to subject other suitable solutions within hermetically sealed flasks, to a degree of heat which, on good evidence, is deemed adequate to kill all pre-existing Living things. If Living things are, notwithstanding the destructive exposure, subsequently to be found in the fluids when the flasks are opened, the evidence would seem to be strongly in favour of the dit novo origination of such Living things-more especially if the heat employed bad been great and long-continued. So far as all direct experiment and observation has hitherto gonc, no Living thing whatsoever has been found to survive in a fluid which has been exposed for two or three minutes to a temperature of $110^{\circ} \mathrm{C}$. And if we couple this fact with a due consicleration of the fundamental unity in Nature of all Living matter, the sul: position that any living things-found in solutions that had been submitted to a far greater heat for two, three, or four hours-hal braved this heat with impunity, would be an assumption seem ingly much more improbable * than the only possible counte supposition, viz., that the Living things had heen evolvel de novo. The former supposition would be less likely to be truc, because, instead of leing consistent or harmonising with ou general knowledge, it would seem to be a mere isolated facl bearing on its face the impress of grave improbability. $B_{i:}$ teric and fungus-spores which cannot, when made the subject of direct observation, resist the infuence of a lower temperature. are, however, to be supposed capable of resisting the influencs of a much higher temperature when their behaviour is watchei by no human eye, though at a juncture when human prejudice emphatically requires that they should do so. $f$ This extreme improbability - this isolated and otherwise unsupported notion -is cherished, whilst the other supposition, which is consistcat with direct observation so far as it can go, and which is thorough y in harmony with a great mass of scientific truth, is rejected. Ais. why is it rejected? Because it is alleged that a great mass of human experience, having no immediate bearing upon this particular subject, and which is only related thereto by analogy, seens to make it improbable. And yet, as a matter of fact, and although precisely the same reasoning is applicable against the alternative which they adopt-if the probability of a present de nozo origination of Living things, after the fashion which is alone maintained, were to be admitted by every scientific man to-morrow, the whole body of human experience would remain perfectly undisturbed. A new probability, akin to a fact, + and one of the most extreme importance, would, it is true, have been added to the sum-total of human knowledge, and the only loss or contradiction would be, that those who had hitherto cherished the formula omne viriznz ex vivo as the expression of a funda mental truth, would have to give it up. Like many another dogma, which in the course of time is toppled over, this expression of an over-hasty, though formerly justifiable, generalisation, now that it has been shown to be incompatible with the latest teachings of science, would have to fall into the shade of cold neglect.

* Although "germs," so far as we know them, are incapable of resisting the influence of great and prolonged heat, it was strggested by Prof. Rolleston, in the discussion which took place in the Biological Section on Sept. 2r, that some germs might exist which were less amenable to the influence of heat, owing to the protein substances entering into their composition being in som. peculiar isomeric state. We know for instance that peptone, which is a modification of albumen, is not coagulable by heat. All that we should deduce from this fact, however, seems to be this, that whereas ordinary albumen modification by which it is rendered insoluble; this same albumen may, by tess, te converted into peptone, a modification which is $n$ capable of being converted into the insolzbble isomeric condition by th. 作 bility; and we must be, as it seems to me, further careful not to mix up ou conception of this property too closely with another which is quite distinct, viz, as to the ability of Living things to withstand the influence of heat.

+ Here we are brought face to face with the real difficulty. In order to explain the results of certain experiments we mztst accept an apparent infraction of one or other of two rules which have hitherto been found to bc universal, so far as human experience has gone. A Living thing has $\mathrm{r}$ more been known to be capable of surviving a temperatue of $150^{\circ} \mathrm{C}$, than another Living thing has been known to arise de novo. Prof. Huxley, and those who think with him appear to forgtt, in their present extreme unwillingness to give up the doctrine olmtze vivum ex vivo, that they can only retaingness to give up the doctrine omzize vivum ex vivo, that they can only retain it by abjuring another doctrine which has a similar seeming univer-
salisty so far as human experience has gone. We have nothing, then, but sality, so tar as human experience has gone. We have nothing, then, but probabilities to guide us in our choice. Hence much difference of opimion which probably exist, till scientific men in general have come to adopt such so ably taught

t All so-called "facts" are, to the philosopher, only possibilities which I A so called "facts" are, to the philosopher, only possibitites "which tivity of Knowledge," so that possibilities, probabilities, and facts, merro insensibly into one another. 
What, then, are the facts which have been made known bearing upon the solution of this question?

Before the date of M. Pasteur's researches, it was generally supposed that Living things' were incapable of surviving in a fiuid which had been raised even for a few minutes to the temperature of $100^{\circ} \mathrm{C}$. ; but, after the results of his experiments, he claimed to have a right to conclude therefrom that, whilst Living things were destroyed in acid fluids which had been raised for a few minutes to the temperature of $100^{\circ} \mathrm{C}$., they were not certainly litlled in alkaline fluids unless these had been raised for a few minutes to a temperature of $110^{\circ} \mathrm{C}$

This, however, is the point at which Prof. Huxley has chosen to close what he considers to be the history of the rise and progress of the doctrine expressed by the phrase omne vivntm ex vivo. Then, ignoring all t that had been done in the interval between the years 1862 and 1870 , he concludes a long but almost irrelevant chain of evidence with an account of three recent (?) experiments of his own, concerning the cogency and worth of which I have already spoken.

But let us briefly glance at the most important work which has been done, in order to throw light upon the subject in dispute, in the interval between the appearance of $M$ Fasteur's memoir in 1862 and the three experiments made by Prof. Huxley himself-work which he so summarily dismisses from notice.

I will say nothing now concerning the various experiments which have been made similar to those of $M$. Pasteur, but with contradictory results ; I will refer rather to experiments in which the flasks and solutions employed have been exposed to a dethe of heat much hioger and much more prolonged than that which was proclained by $M$. Pasteur to be adequate to prevent the occurrence of all organisms in the solutions, and in whicb, revertheless, Living things have been found on opening the flasks. As I have elsewhere mentioned, Prof. Jeffries Wyman, $\S$ of Cambridge, U.S., published an account in 1862 of experiments in which he had boiled fuids containing organic matter for period of two hours, uncler a pressure of two atmospheres, that is to say, at a temperature of $120^{\circ} \cdot 6 \mathrm{C}$. To the fluid so treated, no air was allowed access except what hacl passed through the capillary bores of white-hot iron tubes. And yet, when, after a certain time, the flasks were broken, Living organisms were found in the fluids contained therein. Prof. Mantegazza, $\|$ of Turin, has obtained Living organisms from the fluids of hermetically closed flasks after these, containing the putrescible fluids and common air at ordinary atmospheric pressure, had been subjected for some time to a temperature of $140^{\circ} \mathrm{C}$. Prof. Cantoni, * of Pavia, has found Living bacteria and vibrios in the fluids of similarly-prepared closed flasks, after these had been exposed in a Pepin's digester to a temperature of $142^{\circ} \mathrm{C}$. for fou hours And, lastly, I have myself recorded experiments, t+ made with the kind assistance of Prof. Frankland, showing that Living organisms almost similar to those which have bee ascertained to be incapable of resisting the influence of a fiuid raised to the temperature of $100^{\circ} \mathrm{C}$. for a few minutes may be met with after a time, in solutions which had been exposed in hermetically-sealed and airless flasks, to a temperature varying between $146^{\circ}$ and $153^{\circ} \mathrm{C}$. for a period of four bours. Whilst, by another experiment, ++ it was found that a fungus and spores, as nearly as possible similar to that which bad been found in a living state in one of the former experiments, were all completely disintegrated, §§ after exposture for an equal period, and in a flask

* That M. Pasteur's experiments did not warrant him, however, in coming to the conclusion that Living things were capable of living in an alkaline to the conclusion that living things were capable $100^{\circ}\left(\mathrm{C}^{\circ}\right.$ have endeasolution when this was exposed to a tenperature

voured to show in NATCRE, No. 37, $\mathrm{pp} .224$ 228. of Prof. Tymall, which $f$ With the exception of the recent investigations of pror Tymall, which Prof. Huxley considers capable of supporting his own view of the question, althongh Prof. Tyndall has really done nothing whatever to convince the public that the organic dust which exists in the atmosphere

part made up of the "germs,"

\$ Nature, No. 35, p. I75. Formation of Jiffuroria, E-c." Cambridge, U.

il These experiments were not madc in the interval above referred to, but I de l'Institut, Lombard, t. iii., 1852 .

* See Gaz or. vet. i, 1868, and two communications made to the Royal Lombard Institute, one in April r868, and one in November 1860 .

t+ NATURE, No. 36 .

$\$ 5$ See Nature, No. 37, p. 2rg. The experiment in which the somewhat similar fungus was met with was No. Ig (NATURE, No, $36, p .200$ ), and to this I would particularly direct the reader's attention. The mode of appearance of the fungus, its graclual increase in sire, as well as its microscopical containing a similar solution, to the same temperature of $146^{\circ}$ to $153^{\circ} \mathrm{C}$.

Now, in reference to these results, it should be remarked that there is not one tittle of evidence, so far as I am aware, which can be adduced tending to show that any single Living thing can continue to live in a fluid which is exposed even for a few minutes to a temperature of $110^{\circ} \mathrm{C}$ - -the degree of heat which M. Pasteur thought necessary to ensure the destruction of all pre-existing Living things. And also it has been shown just as definitely that none of the lower Living things which have been submitted to the test, have ever been found to survive an ex posure in $d r y$ air ${ }^{*}$ for $30^{\prime \prime}$ to a temperature of $130^{\circ} \mathrm{C}$. Still less, therefore, would they be capable of withstanding the influence of an extremely condensed vapour at a temperature of $150^{\circ} \mathrm{C}$, or even at $140^{\circ} \mathrm{C}$., for a period of four hours. $t$ There is, at present, no reason whatever for inducing people to believe that the living things met with in the experiments of Professors Wyman, Mantegazza, Cantoni, and those made by myself in concert with Prof Frankland, had been derived from germs which were capable of living through the fiery ordeal to which the flasks had been submitterl, save the extreme reluctance of these people to bring themselves to believe that Liwings things can nowt arise independently of pre-existing Living matter. Moreover, it should be uncierstood, that experiments of this kind seem to be such as are alone capable of aiding us to come to a conclusion on this, the only question in dispute-whether the motionless specks which appear in previously homogeneous solutions, are more likely to have proceeded from the growth of pre-existing invisible germs, 0 : to have arisen quite independently of preexisting Living matter, under the influence of molecular affinities analogous to those which are believed to lead to the formation of similar specks of crystalline matter.

And yet, withont one word concerning the limits of vital resistance; with what must be considered as a tacit admission that the very organisms in question are destroyed in a fluid main tained at a tcmperature of $100^{2} \mathrm{C}$., for 15 minutes; without a single explicit mention of the experiments to which I have just been referring; with a seeming nuter inappreciation of their important bearing upon the great question at issue-Prof Huxley, closing his historical summary with a notice of the labours of M. Pasteur, enrls an almost completely irrelevant statement with the mention of three experiments of his own, which, if they are not to be considered as altogether worthless, are, certainly, of no conceivable value for the establishment of the doctrine which lhe supports, or for the overthrow of the supposition that Living things can at the present time arise dc novo.

Surveying the field of science from the elevated "position in which the suffrages of his colleagues had, for the time, placed him," recognising it as one of his privileges and duties, with "due impartiality," to cleclare "where the advanced posts of science had been drivei in, or a lons-continued siege had made no progress," Prof. Huxley ventures, in the face of the facts above

characters, all point to its having been a living fungus. Whilst the partial preservation of the vacuum for 65 days shows pretty plainly that there was no unobserved crack in the glass. The partial destruction of the vacuum was most probably dine to the liberation of gases within the flask, owing to some decomposition of the tartrate of ammonia during the growth of the fungus. It is not likely that germs contrined in the air conld get throusin a crack, if any stich existed, zulhich aens imperzions to the air itscif

Prof. Tyndall seemed to have completely forgotten all this during the discussion which took place in the Biological Section of the British Association on Wednesday, September $2 x$. He there alleged as his principal reason why the conclusions which I am inclined to draw from my experiments should not be drawn-after I had pointed out to him that $I$ had no asish to exclinde "germs" or Limitu thizors from the flasks which were hermetically sealed,that germs might have adhered to the upper portion of the flask, and might never have come into contact with the heated fluid. But this objection was seen to be futile in the face of the work which had been done concerning the influence of $d r y$ heated air upon lower kinds of Living thingswwork of whose existence Prof. Tyndall seemed to be in ignorance, or which he had entirely forgotten, until he was reminded of the opinions of $M$. Pasteur on entirely iorgotten, until he was reminded of the opimions of $M$. Pasteur on
this subject. Prof. Tyndall, indeed, seented to know very little more of $M$. this subject. Prof. Tyndall, indeed, seemed to know very little more of $\mathrm{M}$.
Pasteur's views than he did of my own. Until it can be shown, however, Pasteur's views than he did of my own. Until it can be shown, however,
that any single minute Living thing can withstand the influence of a conthat any single minute Living thing can withstand the influence of a con-
densed vapour at $x 50^{\circ} \mathrm{C}$., for four hours, the objection which he started so densed vapour at $15^{\circ} \mathrm{C}$., for four hours, the objection which he started so
triumphantly remains and exists only as a highly inprobable supposition, triumphantly remains and exists only as a highly improbable supposition, in the face of which I can again fearlessly state my conclusion-that,
taking all the cyidence as it at present exists, I am as much, even more, taking all the cvidence as it at present exists, 1 am as much, even more,
entitled to believe that the organisms found in my flasks had been evolved de de sovo, than that they had been froduced from pre-existing germs of be by heat.

Even though some of these are quite willing to admit the possibility of such an occurrence, and are ready to accept the notion that in past ages of the earth the first Living matter did so originate from a combination of mere non-living inaterials. 
mentioned, to tell the British Association for the Advancement of Science, and the public generally, that Redi's great doctrine appears to be "victorious along the whole line;" whilst the views and experiments of those who think differently are this referred to:- "On the other side the sole assertions worthy of attention are that hermetically sealed fuids which have been exposed to long-continued heat have sometimes exhibited Living forms of low organisation when they have been opened."

All comments on such a proceeding seem needless-the facts speak only too plainly for themselves.

I will, however, say a few words concerning the mere empty generalities which Prof. Huxley opposes to the definite results of an honest band of workers.

He commences in this way :--"The first reply that suggests itself is the probability that there must be some error about these experiments, because they are performed on an enormous scale every rlay with quite contrary results. Meat, fruits, vegetables, the very materials of the most fermentable and putrescible infusions, are preserved to the extent, I suppose I may say, of thousands of tons every year by a method which is a mere application of Spallanzani's experiment. The matters to be preserved are well boiled in a tin case provided with a small hole, and this hole is soldered up when all the air in the case has been replaced by steam. By this method they may be kept for years without putrefying, fermenting, or getting mouldy." This is a very plausible statement, certainly; and one apparently tencling to confirm Prof. Huxley's views. But what are the real facts of the case? I have made many inquiries and some microscopical examinations during the last three days, the results of which $I$ will now communicate to Prof. Fuxley and others.

Ilaving visited one of the largest establishments in London, and seen the whole process to which the meats and vegetables are submitted for preservation, the information I have to convey is of the most authentic description. For this opportunity, and for many particulars communicated in a long conversation, $Y$ am much indebted to the courtesy of Mr. McCall, of Houndsditch."

A number of cases, enclosing the provisions, instead of being simply heated to a temperature of $212^{\circ} \mathrm{F}$. as most people would understand from what Prof. Huxley said, are first heated in a large chloride of calcium bath (warmed by steam) to a temperature of $230^{\circ}$ to $235^{\circ} \mathrm{F}$. for more than an hour and a half. The hole through which the stean has been issuing is then closed with solder, and as suon as the last of the set has been thus hermetically sealed, a higher pressure of steam is tumed on, by which the bath is quickly raised to a temperature of from $258^{\circ}$ to $260^{\circ} \mathrm{C}$. + -at which temperature it is maintained for more than half an hour. Thus it is now learned that the meats are exposed to a heat of $230^{\circ}$ to $235^{\circ} \mathrm{F}$. for more than one and a half hours, and then to a temperature of $25^{\circ}$ to $260^{\circ} \mathrm{F}$. for another half hour at least. All this is very different from the simple statement that the provisions are "boiled," for a time not specified. Prof. Huxley, in the next place, mentions the possibility of failure, though he seems to attribute all these to "unskilfully closed tins." Now, on inquiry, it appears that the number of unmistakable failures even in the very best establishments is very appreciable, and although many of these failures may be accounted for by defective closure, $\mathrm{Mr}$. McCall assured me that in a certain number of cases, where not the smallest defect could be detected in the tin, where the mode of preparation was unexceptionable, and the provisions originally of the best description, yet for some inscrutable reason some of these tins did prove ntter failures. Gas was found to be evolved within, causing them to bulge at the extremities, and when opened the meats either showed a central decomposition of a most foetid character without mould, or else mould might be found on some portions of the surface. He further assured me that certain tins which had been thoroughly well prepared, and in which the provisions seemed to remain in a perfect state of preservation $\neq$ for two or even three years, might more or less sucldenly show signs of a considerable evolution of gas within, owing to the provisions having fallen into a state of putrefaction. In other instances provisions would keep for ten years

* And also for the kind permission to make known what he had told mo t Whilst I was in this establishment one of the baths was seen to have reached a temperature of $263^{\circ}$. $F$. It was boiling very briskly. The more or less solid contents of the tins would sequire a longer time to be raised to any given temperature than a fluid; so that, practically, the meats may have been exposed only for a comparatively short period to the higher temperatures mentioned. I may state that $230^{\circ}$ and $260^{\circ}$ Fahr., correspond to $x 0^{\circ}$ and $126 \cdot 6^{\circ} \mathrm{C}$.

$\mp$ As judged by evidences of a vacuum within. or more without any appreciable change. I was informed also that turtle, and all the soups which solidified when cold, invariably remained good. Amongst these there were no failures. Mr. McCall was somewhat doubtful as to whether in hot weather, provisions were more prone to fail after severe thunder storms. He had, however, "often thought that electricity" had something to do with the failures. Some of the large retail sellers spoke much more decidedly to me as to the number of failures after thunder. On this question, however, I lay no stress-I merely repeat what I was told.

Wishing to learn what microscopical appearances would be presented by provisions which were sold as being "perfectly good," I procured three specimens from two of the most esteemed retail establishments, informing the original owners that I wished to submit them to a microscopical examination. One of these was a tin of "Julienne Soup," which had been prepared ten months; the second, "Salmon," prepared six months; and the third, "Lobster," only six weeks old. The "Salmon" when opened, had not an altogether pleasant smell; the other two seemed quite fresh. In portions taken from the surface of each, I found the most unmistakable evidences that slight changes had taken place. All presented an abundance of flat granular aggregations, " figure-of- 8 bodies, and a very appreciable quantity of Bacteria and Leptothrix filaments-some of these latter being plain and others jointed. The Leptothrix filaments were mostly about $\frac{1}{30000}$ " in dia. meter. Some of the Bacteria were $\frac{1}{600} "$ in length, and many were moving pretty actively in the specimens taken from the "Julienne" and the "Lobster" figure-of- 8 particles. In the "Salmon," I also found, during my comparatively short examination, two or three portions of Fitngus-filaments, having dis sepiments within, and measuring $\frac{1}{60} \sigma^{\prime \prime}$ " in diameter.

Thus, to sum up, it appears that provisions, prepared as above described, $\$$ which have been exposed for more than two hours and twenty minutes to a temperature varying from $110^{\circ}$ to $126^{\circ} \mathrm{C}$. do, not unfrequently, for $n 0$ discoverable reason, fall into a state of decomposition which renders them useless, and that the only specimens which I have examined microscopically, three in number, all presented evidences that Living things had been growing and developing in the hermetically sealed tins. Why, in some cases, the changes should be so small in extent as not to impair the value of the provisions, and in other cases these changes-passing through the more intermediate gradesshould render the provisions utterly useless, I, or others holding similar opinions, can scarcely be called upon fully to explain. Certain it is, however, that the facts above mentioned, including the circumstance that the failures sometimes take place after the tins have been hermetically sealed for two or three years, and that gelatinous\$ substances are the least prone to change-are all

* Some of these had undoubtedly arisen from a granular degeneration of the meats themselves. Some muscular fibres presented a healthy appear ance, while others were more or less completely granular.

t I may state in reply to what was said by Mr. Eddowes in the discussion on Sept. $2 x$, that trie provisions examined by me had all been prepared by a process essentially similar to that adopted by Mr. McCall. I took care to ascertain this. "The "salmon" was not prepared, as he supposed, in Canada, but by a well-k nown Scotch house.

Since the above was written, I have (Sept. 26) examined two tins which were prepared by Mr. McCall in $186 \mathrm{r}$. One containing "Lamb and Vegeghtinous matter was present. On microsccpical examination I could find "2o trace of organisms. The other tin, containing "Veal and Peas," wa also perfectly good; the odour was just like that of fresh meat. The contents were very dry, not a drop of fluid could be procured, although the slifface was bedewed with a slight moisture. When a small portion, scraped slirface was bedewed with a slight moisture. When a small portion, scraped from the surface and mixed with a drop of water, was examined microscopically, hundreds of extremely minute Bacteria and monilated chains were seen-all either dead, or else extremely langtid. These results are very interesting when compared with what was found in the three

whose contents were much more moist and contained actual fluid. I Without reference to the question whether the Bacteria and Leptothri: flaments were living when seen by me, the very fact of their having been formed in such a very appreciable quantity, seems to make it more probabie that they had been developed after the exposure to the heat within the her metically closed tins, than that they had pre-existed in the fresh provision in the stale in which they were found. There was, however, no reasol whatever for supposing that the Leptothrix flaments were dead, or that the tween which and Brownian movements it is impossible to draw any line of tween which an

demarcation.
It could not be supposed that a gelatinous substance would afford facili-

§It could not be supposed that a gelatizous substance would afford facilities for the molecular rearrangements to take place, without which no new evolution of Living matter would seem possible. On the other hand, if the Living things which are sometimes found in these cases are derived, as many will suppose, from undestroyed germs, it does not seem so easy to under-
stand why they should not germinate on the surface of a gelatinous substand why they should not germinate on the surface of a gelatinous sub-
stance. The "Julieine soup "examined was not gelatinous, it rather stance. The "Julieine soup "examined was not gelatinou
resembled a moderately thick solution of gum in consistence. 
rather strongly in favour of my view, of the case, and will continue to be so, so long as our knowledge concerning the inability of Living things to resist the destructive influence of very high temperatures remains in anything like the same condition as it is at the present day.

Prof. Huxley is inclined to believe that there has been some crior about the experiments recorded by myself and others. IVith regard to my own experiments, however, the chances of crror were certainly diminished to a minimum. Certain fluids were placed in glass vessels, and were handed over to one of the most accomplished chemists in this country, with the simple request that he would extract most of the atmospheric air from the flasks, would seal them hermetically, and would then expose them to a temperature of $150^{\circ} \mathrm{C}$. for four hours. All this is certified by Prof. Frankland to have been faithfully done. * One of the flasks was opened in the presence of Prof. Huxley himself, whilst anothei of them was opened in the presence of Prof. Sharpey; and although the others were opened when I was alone, I hope the results are none the less reliable. In the face of these facts, and of what has been detailed elsewhere, it seems difficult to imagine that the experiments are not really trustworthy. +

Prof. Huxley then concludes his observations on these experiments by saying :- "But if, in the present state of science, the alternative is offered us, either germs can stand a greater heat than has been supposed, or the molecules of dead matter, for no aralid or intelligible reason that is assigned, are able to rearrange themselves into living bodies, exactly such as can be demonstrated to be frequently produced in another way, I cannot understand how choice can be even for a moment doubtful."

Although this climax is thoroughly consistent with the style of the preceding remarks, $I$ find it very difficult to understand why Prof. Huxley should have so much departed from his usua method of argumentation. I should like to ask him, however, whether he considers it the function of a scientific investigator to believe onzly in such seeming possibilities as he can at the ime explain or account for; and also whether he who believes in the analogy between crystals and organisms, + can "assign any valid or intelligible reason" which is likely to be satisfactory to himself or to others, why the constituents of common salt, when in solution, should under certain circum"naces asgresate into crystals of a cubical form; and why, on the other hand, the constituents of sulphate of soda should aggregate into rhombic crystals. Notwithstanding his inability to xplain these facts, I suppose be nevertheless accepts them as facts, even although in the case of sulphate of soda, almost exactly the same kinds of crystals result, zuhcther they have pro cieded from pre-cxisting crystilline germs, or whether they have arisen de notio. S Prof. Huxley seems only too much to overlook the fact that what may be perfectly inexplicable from one point of view, may, on the contrary, flow as a necessary consequence from one of an opposite nature. Although, therefore, as a disciple of Redi, the facts to which he has alluded may seem diffcult to explain, Prof. Huxley must recollect that two rival doctrines are in question. And having two doctrines of almost ecjual probability to decide beiween, it seems to me mere childishness to reject a certain well-supported interpretation simply

* See his description of the process, NatuRE, No. 36 , p. Ig9.

t The possibilities of error, which in a previous discussion (on Sept. 20) in the Biological Section, seem to have been suggested by Prof. Huxley, were two in number. First, that unperceived cracks may have Huxley, were two in number. First, that unperceived cracks may have
been present in the hermetically sealed flasks, and second, that objects supbeen present in the hermetically sealed flasks, and second, that objects sup-
posed to have been Living, may not have been so in reality. I have already posed to have been Liritig, may not have been so in reality. I have already
spoken of these possibilities with reference to Exp. rg, and there is no spoken of these possibilities with reference to Exp. I9, and there is no better ground for either of the suppositions in
and 2o. (See NAture, No. 36, pp. rg9-201.)

and 2o. (See NATuRE, No. 36, pp. 199-201

See quotation, NASURE, No. 46, p. 4ri. $\$$ There is a very slight difference in the form of the crystals in the two cases, because in order to make sure of the absence of crystalline germs,
t'he new crystals have to form urider a different and exceptional set of condithe new crystals have to form urider a different and exceptional set of conditions. But, notwithstanding what Prof. Huxley says, we find even a more striking divergence occasionally, in the case of organisms, which possibly
have been evolved from similar materials though under different conditions. have been evolved from similar materials though under different conditions. have elsewhere said (NATtRE, No. 37, p. 223):- "We find also associated
with different sets of conditions, different kinds of Living things. In none of the with different sets of conditions, different kinds of Living things. In none of the crystals of tartrate of ammonia have $I$ ever found a single distinct bacterium, and there has been the same complete absence of organisms of this kind in soda, which have been sealed up in vacko. This agreement is very striking seeing that whenever a similar fltid, or a solution of tartrate of ammoni alone, is exposed to the air, then bacteria appear in abundance. There is a marked accordance, then, between the organisms which are produced in the experimental tubes in $v a c u o$, and those which come from the cavities within the crystals," whilst these differ altogether from those which are met with in a similar solution exposed to the air. (See also what is said in Note on same page concerning the occurrence of Sarcina. because it is inexplicable on the one hypothesis, and to think that this inexplicability is an argument against the interpretation given, when, so far from being inexplicable, this, in the light of the counter hypothesis; is nothing else than a logical consequence. That some such similarity as that which is alluded to should exist, is only to be expected by those who believe that the lowest living things are but the products of the molectlar properties of a complex matter, and the "conditions" acting thereupon." I entirely agree with Mr. G. H. Lewes, when, in a most valuable essay, the points out that "similarity in the laws and conditions of Organic Combination must produce similarity in organisms, independently of relationship, just as similarity in the laws and conditions of inorganic combination will produce identity in chemical species." It is the extreme complexity of the materials in the one case, and their corresponding sensitiveness to modifying infuences, which make it hopeless for us to think of ever getting the same uniformity of results, which we are able to attain when we have to do with simple inorganic materials. The difference, however, is one of degree, not of kind.

I enter a protest, therefore, against the first portion of Prof. Huxley's Inaugural Address, for the following reasons :-

I. Because it does not seem to be characterised by "due impartiality."

2. Because it is calculated to mislead the public; since what is represented as relevant and of first importance, has only an indirect bearing on the sulject: Abundance or paucity of gesms in atmosphere.

3. Because the real issues having already been pointed out by others, Prof. Huxley ignoring these, approaches the problem as though they had never been stated, and as though he himself were not aware 'of them: Mode of origin of specks of Lizing matter in apparently homogenzous solutions.

4. Because it allows room for the inference, and even suggests it, that evidence which is generally admitted to be of the greatest importance for the solution of the question in dispute, is really of little or no importance : Limits of vital resistance to heat, and presence of Living organisms in closed vessels which had been previously exposed to great heat.

5. Because, without any sufficient warrant, it throws doubt upon the "trustworthiness" of certain experiments, of whose real nature his audience and the public are not informed: Experiments of Wyman, Mantegazza, Cantoni, \&c.

6. Because it opposes the definite results of these experiments by nothing but insufficient statements, and what appear to be crude suppositions: Statements and assumptions conceming preserved meats.

The general effect being, I conceive, an entire misrepresenta. tion of the present state of knowledge upon the questions concerning the Origin of Life, which are at present under cliscussion.

ir. Charlion Bastian

** Owing to the great pressure on our space, we are compelled to postpone several articles of real value which are already in type.

\section{LETTERS TO THE EDITOR}

[The Editor does not hold himself responsible for opinions expressed by his Correspondents; No notice is tak:n of anonymous communications.]

\section{University College Lectures for Ladies}

IN this week's number of NATURE I see it noted that among the courses of lectures announced for the ensuing winter by the Ladies' Educational Association in connection with University College, are included two upon scientific subjects (chemistry and experimental physics). May I venture to point out that the prospectus makes mention also of a third, namely, on logic, introduced by ten lectures on the psychology of intellect? This course

* It is difficult, almost impossible, for us to say how far seemingly great differences in corditions, are really very different in respect to the influences which are most potential in leading the not-living to assume Living modes of combination, because we do not know for certain what these most potential factors are, and therefore how far these may be present or absent under circumstances apparently dissimilar.

† "Darwin's Hypothesis." Fortuightly Reviend, April 1868, p. 372. 